\title{
Association of Physical Workload with Salivary Cortisol in Clinincal Pharmacist
}

\author{
Errisa Sulfiana1, Abdul Rohim Tualeka2, Noeroel Widajati2
}

IStudent in Magister of Occupational Health and Safety, 2 Lecturer in Department of Occupational Health and Safety, Faculty of Public Health, Airlangga University, Campus C Mulyorejo, Surabaya-Indonesia

\begin{abstract}
Objectives: Identify physical workload, identify salivary cortical levels in clinical pharmacist, analyze physical workload and cortical levels in clinical pharmacist Method: using calorimeter HR watch to measure physical workload specifically for work metabolic, and using ECLIA method to measure salivary cortical Results: There was a $47.1 \%$ correlation between physical workload and cortical levels.
\end{abstract}

Keywords : Pharmacist, Workload, Stress, And Salivary Cortisol.

\section{BACKGROUND}

Prolonged negative stress can affect physical and psychological health. Its called distress, can affects the intentions, appearance and daily behavior while working, if the level of distress increases in a company and industry, then there will be decreased performance and the emergence of several diseases caused by stress 27 . Reaction to stress, in the defense mechanism of the body, physically and psychology known as General Adaptation Syndrome (GAS) 27. There are consist of, the first stage is the alarm stage, then the stage of survival and fatigue stage 27. At the alarm stage is notification to the body about events that are not in accordance with the expectations, it is necessary to adjust psychologically by physiological coping and adjustment mechanism, where this phase of the body began to secrete hormones for defense. In the autonomic nervous system there are two processes that must run simultaneously when the stress is approaching, the sympathetic nervous system that makes coping mechanisms and parasympathetic nervous system responsible for the increase of the hormone cortisol 27.

\section{Corresponding author:}

Dr. Abdul Rohim Tualeka

Lecturer in Department of Occupational Health and Safety, Faculty of Public Health, Airlangga University Campus C Mulyorejo 60115 Surabaya-Indonesia, Email: Inzut.tualeka@gmail.com
When stress comes, the kidney-parasympathetic kidney system (the adrenal cortex) secretes excessive hormones through the central nervous system of the pituitary gland. The hormone cortisol will affect the metabolism of proteins, carbohydrates and fats in the body. The protein synthesis is reduced and glucose production is enhanced by the mobilization of glycogen reserves, as well as the release of fatty acids into the blood. As a result of these changes, the body can adapt to stressful pressures that threaten it, and therefore cortical plays an important role in the metabolism of carbohydrates. The effect of catabolism from cortical causes the inhibition of protein formation of amino acids, whereas glucose conversion is accelerated, whereas potassium increases excretion by maintaining electrolyte and water balance.

Measurement of cortical in the body especially in the salivary glands has been set as a bio indicator of individual stress response 20 . There is a significant relationship between cortical in saliva and the hormone cortical in the body28. Cortical in saliva occurs as a result of activation by the adrenal cortex gland at the alarm stage of the general adaptation syndrome process. Therefore long-lasting stress will continuously increased with very different levels as normal cortical as usual in the body. This will cause changes in function and hormones in the body that should be in a state of normal and down at night but levels remain high at night, especially the hormone cortisol ${ }_{11}$. 
The greatest factor of job stress in the pharmaceutical worker is the result of much work to be done. That Caused also by a change of mindset and the times, of which initially only aimed for an increase in drug services turn out to be an increase in services to patients13. In Johnson et al (2014) study due to overworked workload and the large number of duties of pharmaceutical workers, the turn-over rate increased as well as the occurrence of burn-out syndrome due to the very defeat, causing illness to the pharmaceutical workers. Physiologically, when pharmaceutical workers, are required to work effectively and efficiently, the body will release hormones to match the workload. The hormone release cortical that is needed in the metabolism of carbohydrates and fats for energy formation will soon be adjusted to the needs of the worker's body. This situation is abnormal if the load exceeds the limit that is given that could not be tolerated to cause mental and physical stress, and ultimately change concentrations several hormones in the body quickly 11 . The level of salivary cortical before work and after work can be a biomarker of stress level of physical and mental effort pharmacy so that mistakes in work such as medication errors, and achieve productivity with efficiency and effectiveness in working on the recipe and do not damage the health of workers .

\section{MATERIALS AND METHOD}

The study conducted in Pharmacy Installation of Bhakti Dharma Husada General Hospital, Surabaya, East Java province, Indonesia. Population of the study were clinical pharmacist under the pharmacy installation, and worked on emergency unit, outpatient unit, inpatient unit, and drug warehouse, with total population of 20 clinical pharmacist. The variables in this study were cortical in saliva as dependent variable, and physical workload as independent variable. The physical workload is measured using calorimeter HR watch. The calorimeter used for 4 hours as long as they work. Levels of salivary cortical were measured using the ECLIA method (electron chemo luminescent immune assay) taken during and before work.

\section{RESULTS AND DISCUSSION}

Pharmaceutical activity such as pharmaceutical preparation, medical devices and medical consumables and clinical pharmacy services demanding very heavy and exhausting physical and mental activity. As a result of physical and mental activity there is an imbalance between the tasks that must be done by pharmaceutical personnel with physiological capacity owned by pharmaceutical workers. This imbalance causes adaptation mechanism. At the time of the adaptation mechanism the body will activate the HPA axis, by producing a large cortical and channeled to several organs for use as a mechanism of body adaptation to workload. This is done so that the body can perform metabolic processes to produce enough energy to meet the physical and mental demands of pharmaceutical personnel.

Physical work is an activity to complete a job requiring physical energy in the human muscle that will serve as a source of energy. Physical work will be entirely dependent on human efforts that serve as a source of energy and work control. Physical demands on pharmaceutical workers such as work stations, workplace layouts, work tools and equipment, working conditions or workplace, work attitude. Physical demands require muscle work during the working period, and energy consumption is a major factor in making the benchmark determinants of weight / light of a job.

The physical work load measuring instrument uses the ultimate gear calorimeter watch. Pharmaceutical workers in pairs of these tools when they start to work and released after the respondents use these watches for 4 hours they work. This HR watch calorimeter works by keeping track of the calories released by the user's body, the calories in the can from the results of metabolism. Metabolism is a chemical process to change some substances especially carbohydrates out heat, that heat will be recorded by the calorimeter. The metabolic process is strongly influenced by the body area then height and weight data is required. If the metabolism process occurs then the activation of HPA axis also occurs, because HPA axis is the activating process of metabolism.

The results of measurements of 16 pharmaceutical workers to remove calories of $100-200$ calories and included in the category of light workload, while 4 people remove calories from 201 to 350 calories and included the category of medium workload. Pharmaceutical work is a category of light work, because pharmaceutical work does not require much muscle activity. The results of the observation of the respondents are more like entering patient data, preparing recipe and communication to fellow colleagues. Activities that are not in a sitting position are when taking drugs on shelves, in warehouses, 
counseling with patients and distributing drugs to the spaces and visit with other colleagues.

The measurement of the physical workload using the calorimeter becomes less precise because the number recorded on the monitor is the heat released by the body due to metabolism, while the pharmaceutical work in the cold and moist heat, so that the release of body heat is hampered by cold room. The cold room is required to maintain the stability of drugs stored in the same room where the pharmacy works. Physical workload will produce fairly accurate results if measured not only calories, but calculate the overall energy needs10. Energy requirements are needed for basal metabolism, metabolism rest and metabolism work.

The result of statistical analysis, the correlation coefficient of kendall-tau obtained is 0.228 , with the strength of the relationship of $47.1 \%$. Correlation coefficient is a test to see how the relationship between independent and bounded variables. Coefficient is 0.228 can be said to be closer to the number 0 which means having a weak relationship, with the strength of the relationship is only $47.1 \%$. The relationship between the variables is weak because the researchers only perform the measurement of 1 metabolism results alone, while for measure physical workload in need calculate the total metabolism. Levels of cortical have metabolic functions throughout the body so it needs to be measured overall as basal metabolism and rest should also be measured. The researchers did not make the measurements because of the limitations of pulse measuring devices, heart rate measurers, and health workers in hospitals unlike workers who have hours of rest because the service to patients is preferred if doing a complete measurement will disrupt the pharmaceutical job.

Results from the measurement of cortical levels 20 pharmaceutical population of 5 people had elevated levels of cortical after work. When viewed from the workload that tends to be mild and moderate, 5 pharmaceutical workers are producing excessive levels of cortical. This abnormal level of cortical may occur because the pharmaceutical worker must continue to perform all of the pharmaceutical work to serve the patient, other peers, while in the body continuously activates the HPA axis pressure, causing cortical levels that do not follow the rhythm diurnal with the level high because it always activates cortical secretion.
According to Manauba (2000), task demands in this case the task and material characteristics, organizational characteristics and environmental characteristics must be balanced with a person's work ability, if the demands of work are too low or too high will cause stress. Judging from the demands of pharmaceutical work is in need of speed and accuracy, while the physiological ability of the pharmaceutical workers is cortical levels in abnormal circumstances, there is an upside down situation. This situation is turning to prepare a work full of pressure so that the body is always vigilant. Jobs that are too low because of the work of pharmacy is a job that is not much use of muscle, so that energy is not much for physical activity but mental activity, so it needs to do a review related to the pharmaceutical task in do 5 people. Working efficiently is expected to increase the rest time so that it can be productive again, while not working for 1 month, it is necessary to reduce the task because the pharmaceutical worker is still in the process of adjusting the given task.

\section{CONCLUSION}

Physical workload for clinical pharmacist in pharmaceutical installations in hospitals account for 16 pharmaceutical workers have calories of $100-200$ calories in the category of light workload, while 4 people have calories from 201 to 350 calories and in the category of medium workload There is a weak correlation between the physical workload is 0,228 with the strength of the relationship is only $47.1 \%$.

\section{Conflict of Interest: None}

Source of Funding: Department of Occupational Health and Safety, Public Health Faculty, Airlangga University, Surabaya, Indonesia

Ethical Clearance: The research proposal has been approved by Health Research Ethical Commission of Public Health Faculty Airlangga University, number: 540-KEPK. All respondents were given explanation and information about the purposes and methods of the research, and also had signed informed consent forms.

\section{REFERENCES}

1. Batista, Patricia. Anabela Pereira. Ana Beatrz Vaz. (2017) Salivary Biomarkers In Psychological Stress Diagnosis. ARC Journal Of Pharmaceutical Sciences. Vol. 3 February 2017. Pages 9 -18 
2. Beall, Jeninifer W. Renee M. DeHart. Robert M.Riggs. John Hensley. (2015) Perceived Stress, Stressors, And Coping Mechanism Among Doctor of Pharmacy Student. Pharmacy 3. November 2015. Pages 344-354

3. Bozovic, Djordje. Maja Rajic. Nedeljka Ivkovic. (2013) Salivary Cortisol Levels as a Biological Marker Of Stress Reaction. Med Arh. October 2013. Pages $371-374$

4. Burke, Heather M. Mary C. Davis. Christian Otte, David C. Mohr. (2005) Depression And Cortisol Response To Physiological Stress : A Meta Analysis. Elsevier LTd. 30.February 2005. Pages 845 - 846

5. Carnagie, Rebecca. et. al (2017) Cortisol Awakening Response and Subsequent Depression : Prospective longitudinal study. The British Journal Of Pshychiatry 204 .January 2017. Pages 137-143

6. Haryanti, Faridah Aini, Puji Purwaningsih. (2013) .Relationship Between Workload With Stress Work Nurse At Emergency Installation Hospital Semarang Regency. Journal of Nursing Management. Vol. 1.No.1 . Mei 2013. Pages $48-56$

7. Hellhammer, Dirk H. Stefan Wust. Brigitte M. Kudeilka. (2009). Salivary Cortisol as Biomarker In Stress Research. Elsevier. Vol. 34.Pages 163 - 171

8. Imron TA, Moch (2010). Health Sector Methodology. Surabaya: PT. Sagung Seto, Pages 117-112

9. Imron, Akhmad, (2014). Factors Affecting Working Stress In Children Fruit Ship (Study On Passenger Ship and Ship Goods at Port of Tanjung Perak Surabaya). Thesis. FKM University of Airlangga.

10. Iridiastadi Hardianto, Yassierli, (2016). Ergonomics An Introduction. Bandung: PT. Remaja Rosdakarya, Pages $151-183$

11. Ivkovic, Nedeljka. Et al .(2015). Biomarkers of Stress in Saliva .Scientific Journal of The Faculty Of Medicine in Nis. Vol. 32.Pages 91 - 99

12. Jobin, Joelle. Carsten Worsch, Michael F. Scheier. (2014) Associations Between Dispositional Optimist And Diurnal Cortisol in a Community Sample : When Stress Is Perceived As Higher Than Normal. Health Psychol. 33 (4). April 2014. Pages 382 - 391
13. Johnson. S.J. et. al (2014) The Relationships Among Work Stress, Strain And Self Reported Errors in UK Community Pharmacy. Elsevier Inc. 2014 Vol 1

14. Jung, Christopher. M et. al (2010). Acute Effect of Bright Light Exposure on Cortisol Levels .J Biol Rhythm. Vol. 3.Juni 2010.Pages $208-216$

15. Koh, David Soo-Quee. Gerald Chon-Nuat Koh (2007). The Use Of Salivary Biomarkers In Occuptional And Environmental Medicine. Occupational Environment Medicine. Vol. 64. 2007. Pages 202 - 210

16. Lentjes, E.G.W.M, F.H.T.P.M. Romjin (1999) Temperature-Dependent Cortisol Distribution Among The Blood Compartment in Man. J Clin Endocrinol Metab. Vol. 84. 1999. Pages 682 - 687

17. Maurits, Lientje Setyawati K. (2010).Overview About Work Fatigue. Yogyakarta : Amara Books 2010

18. McCann, Laura et. al. (2009). Assessing Job Satisfaction And Stress Among Pharmacists In Northern Ireland. Pharm World Sci 31 . January 2009.Pages $188-194$

19. Munger, Mark A. et. al. (2013) Community Pharmacist Occupational Satisfaction And Stress : A Profession In Jeopardy. Journal Of The American Pharmacists Association 53 .Juni 2013. Pages 282 - 296

20. Nakajima, Yasushi. et. al. (2012) Patterns Of Salivary Cortisol Level Can Manifest Work Stress in Emergency Care Providers. Journal Physiol Sci 62 (3). Mei 2012. Pages $191-197$

21. NIOSH, (2014).Exposure To Stress Occupational Hazard In Hospital. NIOSH

22. Ojerinde, Abosede Catherine, Prisca Olabisi Adejumo, (2014) Factors Associated With Medication Errors Among Health Workers in University College Hospital Nigeria. Journal of Nursing and Health Science.Vol.3. June 2014.Pages 22-33

23. Olds, Danielle. M, Sean P.Clarke (2010) The Effect of Work Hours on Adverse Events and Errors in Health Care. Journal Safety.Vol.41 No.2. April 2010. Pages 153-162 
24. Rasfa, Asrar Fuad, Cecelia SW, Arie Desrianty. (2014). Mental Load Evaluation Machinist by the Subjective Workload Assessment Technique (SWAT) and amylase activity in saliva, Online Journal National Institute of Technology.Vol.1. No.4.April 2014.Pages $90-97$

25. Rehan, Harmeet Singh, Shashikinant Bharvaga. (2015). Medication Errors are Preventable. Journal Pharmacovigilane. Juni 2015

26. Rothmann, Sebastian (2007) Occupational Stress of Hospital Pharmacist In South Africa. International Journal Pharmacy Practice 15 . April 2007. Pages $1-8$

27. Selye H. A Syndrome of produced by diverse nocuous agents. Nature 138:32

28. Seo, Sang Hee. (2016) Detection of Chronic Stress Using Bio-Signals. Indian Journal of Science And Technology. Vol. 9 No.46. December 2016.

29. Sugiatmajaya, Safaat, Cecelia SW, Yuniar, (2014). Evaluation of Stress Levels of Machines based on Salivary Alpha-Amylase Activity (Case Study at PT Kereta Api Indonesis Area Operasi 2 Bandung), Journal Online National Institute of Technology. Vol.2. No.2.October 2014. Pages 90 - 97

30. Sugiyono, (2016).Research Methods, Quantitative, Qualitative, and R \& D. Bandung: Publisher Alfabeta, Pages 30 -166.

31. Suma'mur. (2014) Company Hygiene and Occupational Health (Hiperkes).Surabaya : Sagung Seto 2014
32. Taban, Ebrahim, et, al (2016) Noise Exposure Effect On Blood Glucose, Cortisol and Weight Changes in The Male Mice, Journal Health scope. 18 July 2016

33. Tajuddin Rusmi Sari, Indrianty Sudirman, Almin Maldin. (2012). Factor Causes Medication Error On Emergency Treatment installation. Journal of Health Services Management.Vol.15. No.4.December 2012.Pages. 182 -187

34. Tarwaka (2011). Industrial Ergonomics: The Basics of Ergonomic Knowledge and Application in the Workplace. Solo : Harapan Press 2015. Pages $103-141$

35. Thayer, J.F, et, al (2010) Effect of the Physical Work Environment on psychological Measures of Stress. Europe journal cardiovascular Prev Rehabil.Vol. 17. August 2010. Pages 431 -439

36. Tsao, Nicole. W et, al (2014) Decentralized Automated Dispensing Devise : Systematic Review Of Clinical \& Economic Impact For Hospital. The Canadian Journal Of Hospital Pharmacy. March - April 2014. Pages 138 -148

37. Utami, (2016).The Role of Spiritual Training Dzikir Against Changes Of Perception And Improvement Distress Bargain In Hospital. Dissertation. FKM University of Airlangga

38. Widajati, Noeroel (2015). Development of NIOSH Model About Unsafe Action On Job Stress Condition of Production Workers at Steel Construction Company. Dissertation. FKM University of Airlangga

39. Wijono Sutarto, (2014). Industrial Psychology \& Organization. Revised Edition. Jakarta: Pt. Kencana Perdana Media Grup, Pages 143 - 166. 
